\title{
CO-RELATION BETWEEN FIRST TRIMESTER URIC ACID CONCENTRATION AND DEVELOPMENT OF GESTATIONAL DIABETES MELLITUS
}

Shery Angel Rajakumar ${ }^{1}$, Thirumal R², Usha V33, Rontgen $\mathrm{R}^{4}$

\section{HOW TO CITE THIS ARTICLE:}

Shery Angel Rajakumar, Thirumal R, Usha V, Rontgen R. "Co-Relation between First Trimester Uric Acid Concentration and Development of Gestational Diabetes Mellitus". Journal of Evolution of Medical and Dental Sciences 2014; Vol. 3, Issue 02, January 13; Page: 266-271, DOI:10.14260/jemds/2014/1820

ABSTRACT: Gestational diabetes mellitus (GDM) is defined by the World Health Organization (WHO) as a carbohydrate intolerance resulting in hyperglycemia of varying severity with onset or first recognition during pregnancy ${ }^{1}$ (WHO, 1999). The present study was done to find out the correlation between $1^{\text {st }}$ trimester uric acid concentration and the development of GDM. GDM was diagnosed based on the OGCT and GTT test. Study was done in a total of 1002 patients. Uric acid concentration of $>3.6 \mathrm{mg} / \mathrm{dl}$ was considered abnormal (AJOG, vol201, oct2009)2.749 patients had normal uric acid and 253 patients had abnormal uric acid. A total of 65 patients were diagnosed to have GDM (6.48\%).

KEY WORDS: Gestational diabetes mellitus, oral Glucose challenge test, oral Glucose tolerance test, uric acid.

\section{INTRODUCTION:}

Gestational diabetes (or gestational diabetes mellitus, GDM) is a condition in which women without previously diagnosed diabetes exhibithigh blood glucose levels during pregnancy ${ }^{3}$. Gestational diabetes is caused when the body of a pregnant woman does not secrete excess insulin required during pregnancy leading to increased blood sugar levels ${ }^{5}$. Gestational diabetes affects 3 $10 \%$ of pregnancies, depending on the population studied 1 .

Uric acid is the end product of purine catabolism catalyzed by the enzyme xanthine oxidase/dehydrogenase. In non-pregnant women, uric acid is associated with insulinresistance ${ }^{6}$ and is an independent risk factor for development type 2diabetes within 10 years. Two mechanisms have been hypothesized by which uric acid can cause insulin resistance, the first proposed that uric acid causes endothelial dysfunction and decreases nitric oxide production by the endothelial cell. Insulin action on glucose uptake into cells in the skeletal muscle and adipose tissue is dependent on nitric oxide thus, decreases in nitric oxide lead to decreased glucose uptake and the development of insulin resistance. Another mechanism by which uric acid may induce insulin resistance may be that uric acid causes inflammation and oxidative stress in adipocytes, which is a contributor to the development of metabolic syndrome in mice. ${ }^{2}$

MATERIALS AND METHODS: Prospective study of 1002 patients conducted in the department of obstetrics and gynecology in SRMC, Chennai. Aim of the work explained to all pregnant women.

INCLUSION CRITERIA - antenatal women in their $1^{\text {st }}$ trimester of pregnancy $(<12$ weeks of gestation)

EXCLUSION CRITERIA - Renal disease, liver disease, pre gestational diabetes, chronic hypertension, gout, smoking and alcohol intake, drugs that increase uric acid level in pregnancy example: Aspirin, diuretics, phenothiazines. 
STUDY DESIGN: Maternal plasma uric acid is measured before 13 weeks of gestation from venous sample, it is measured using a calorimetric assay with a detection limit of $10 \mathrm{mg} / \mathrm{dl}$. The cut off taken in my study is $3.6 \mathrm{mg} / \mathrm{dl}$ (AJOG, vol201, oct2009). Later, screening for GDM is done in these patients. All patients underwent random OGCT (50gms) between 24-28 weeks. If plasma glucose level $>140 \mathrm{mg} / \mathrm{dl}$ then the patient is at increased risk of developing GDM, the patient is then subjected to a oral GTT(100gms).FBS value, $1 \mathrm{hr}, 2 \mathrm{hr}, 3 \mathrm{hr}$ blood glucose value measured and interpreted according to carpenter and coustan criteria (ADA 2009).

OBSERVATION: The study was conducted in a total of 1002 patients. 365 (36.43\%) multigravida and $637(63.57 \%)$ primigravida. uric acid $>3.6 \mathrm{mg} / \mathrm{dl}$ was considered abnormal. 749 (74.75\%) patients had normal uric acid and 253(25.25\%) patients had abnormal uric acid. Spot test was $>200$ $\mathrm{mg} / \mathrm{dl}$ in 2 patients (0.2\%), 140mg/dl - 200mg/dl in 112 (11\%) patients, <140mg/dl in 888(89\%) patients. A total of 65 patients were diagnosed to have GDM (6.48\%).
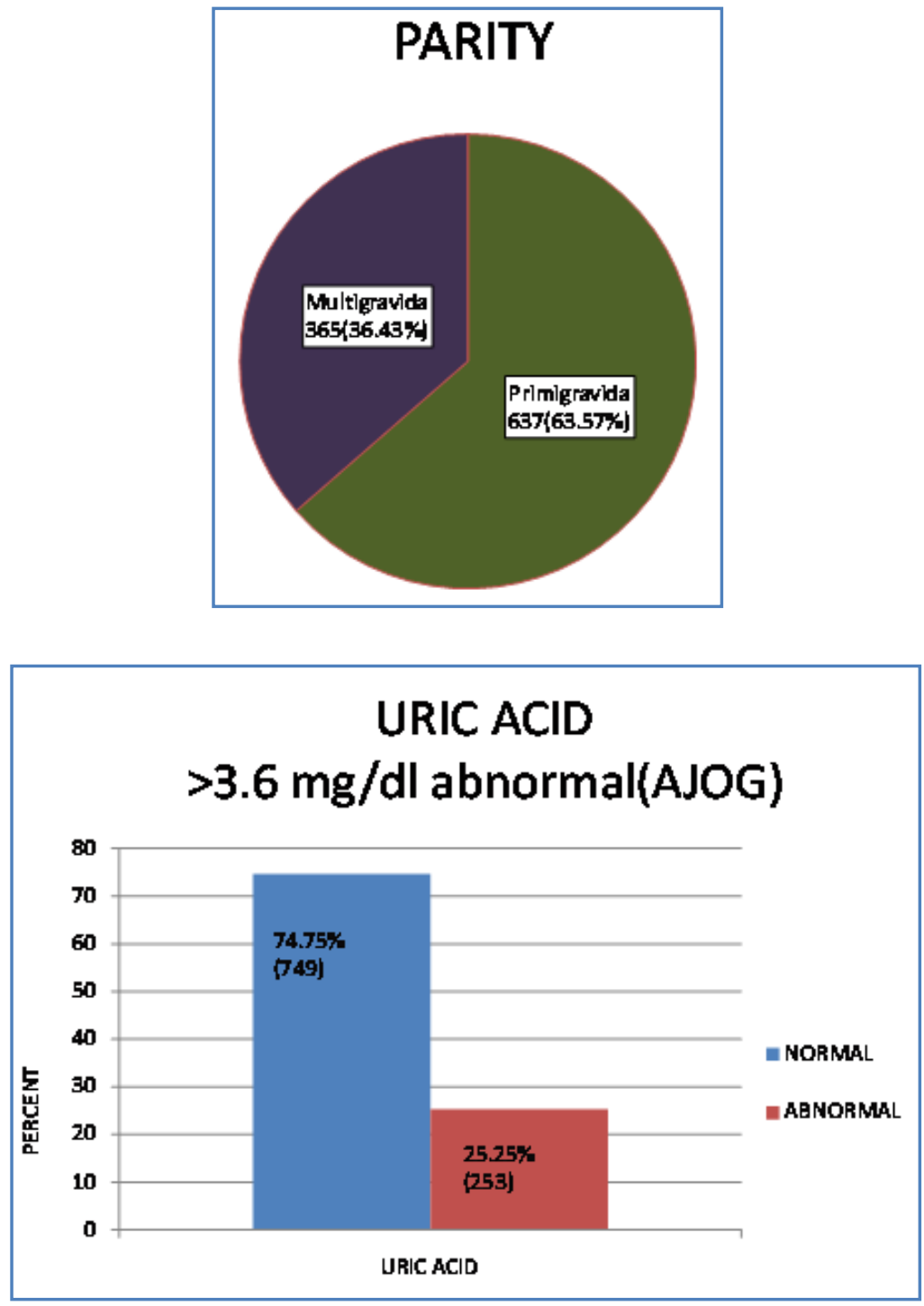


\section{ORIGINAL ARTICLE}
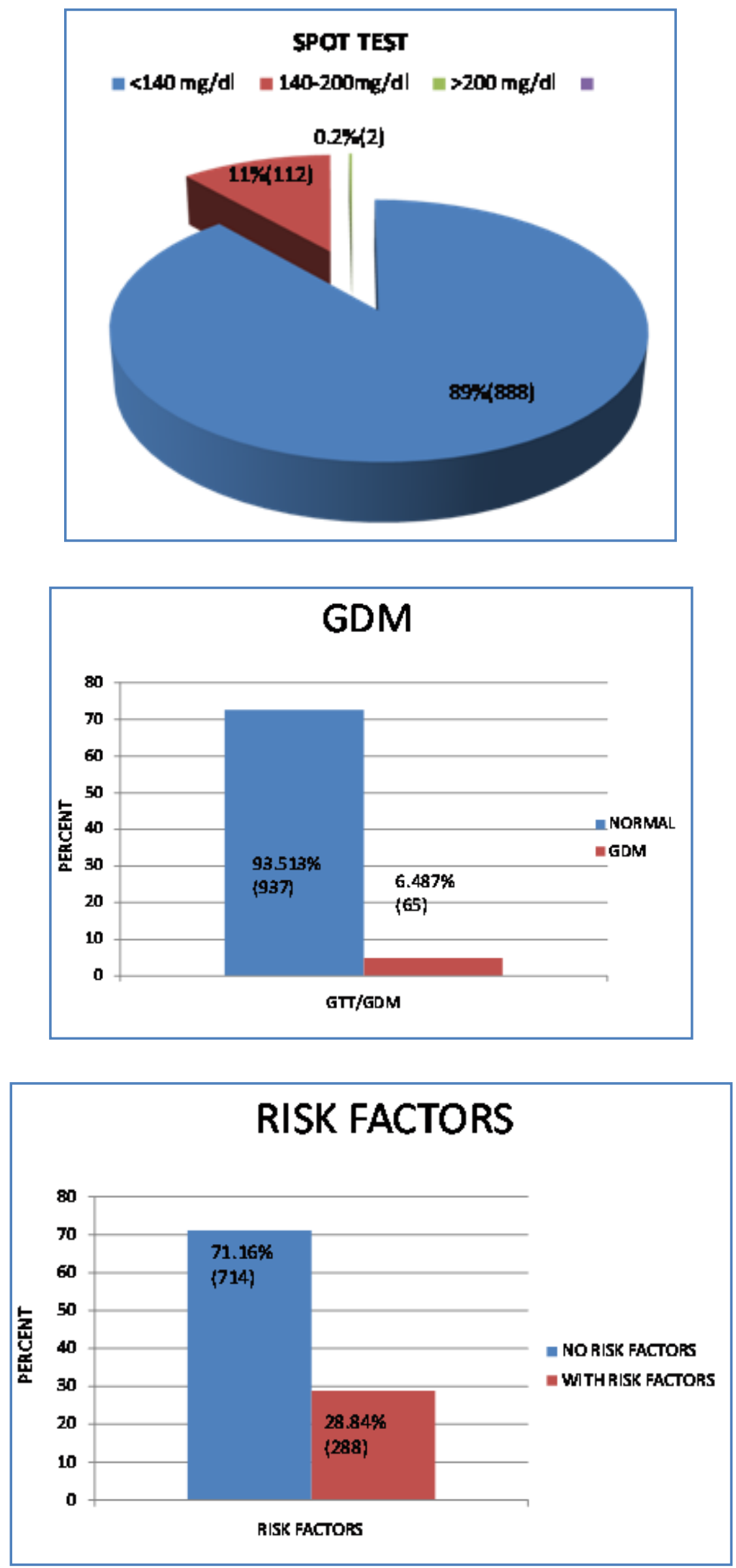
Out of the 1002 patients no risk factors for GDM were noted in 714 patients $(71.16 \%)$ and risk factors were noted in 288 patients (28.84\%). Patients with normal uric acid and developing GDM were 24 patients (3.2\%). Patients with abnormal uric acid and developing GDM were 41 patients $(16.21 \%)$.

DISCUSSION: GDM is a common medical problem that results from an increased severity of insulin resistance as well as an impairment of the compensatory increase in insulin secretion. ${ }^{3}$ Pregnancy in essence serves as a metabolic stress test and uncovers underlying insulin resistance and beta cell dysfunction.GDM is associated with a variety of maternal and fetal complications, most notably macrosomia $^{4}$ (fang et al, 2006)

\begin{tabular}{|l|c|c|}
\hline \multicolumn{1}{|c|}{ Uric Acid } & $<3.6 \mathrm{mg} / \mathrm{dl}$ & Gestational Diabetes Mellitus \\
\hline Normal (749) & 725 & 24 \\
\hline Abnormal (253) & 212 & 41 \\
\hline
\end{tabular}

URIC ACID CONCENTRATION AND DEVELOPMENT OF GDM

Therefore it was noticed that out of the 749 patients with normal uric acid 24 patients developed GDM (3.2\%) and out of the 253 patients with raised uric acid concentration 41patients developed GDM (16.21\%) $\mathbf{P}=\mathbf{0 . 0 0 3}$ hence significant.

\section{SECONDARY OBSERVATION:}

RISK FACTORS

Risk factors were present in 288 patients (28.84\%)

No Risk factors in 714 patients $(71.16 \%)$

Patients with normal and abnormal URIC ACID were studied in relation to their RISK factors and were found that

\begin{tabular}{|c|c|c|c|}
\hline & & RISK ++ & No RISK \\
\hline Normal UA & 749 & 128 & 621 \\
\hline Abnormal UA & 253 & 160 & 93 \\
\hline
\end{tabular}

\begin{tabular}{|c|c|c|}
\hline URIC ACID NORMAL & RISK FACTOR & NO RISK FACTOR \\
\hline 749 & 128 & 621 \\
\hline GDM in this group(total) & 20 & 4 \\
\hline $\begin{array}{r}\text { RELATION OF NORMAL URIC ACID CONCENTRATION WITH } \\
\text { RISK FACTOR AND DEVELOPMENT OF GDM }\end{array}$ \\
\hline
\end{tabular}

Therefore, patients with normal uric acid and with risk factors developing GDM were 20 patients $(15.63 \%)$

$\mathrm{p}=0.6$ hence not significant

\begin{tabular}{|c|c|c|}
\hline URIC ACID ABNORMAL & RISK FACTOR & NO RISK FACTOR \\
\hline 253 & 160 & 93 \\
\hline GDM in this group (total) & 25 & 16 \\
\hline
\end{tabular}

RELATION OF ABNORMAL URIC ACID CONCENTRATION WITH RISK FACTOR AND DEVELOPMENT OF GDM 
Therefore, patients with abnormal uric acid and with risk factors developing GDM were 25 patients $(15 \%)$

$\mathrm{p}=0.008$ hence significant

\begin{tabular}{|c|c|c|}
\hline & RISK FACTOR & NO RISK FACTOR \\
\hline & 288 & 714 \\
\hline GDM (total =49) & 45 & 20 \\
\hline \multicolumn{2}{|c|}{ DEVELOPMENT OF RISK FACTOR AND GDM } \\
\hline
\end{tabular}

Therefore, 45 patients developed GDM of the 288 patients with risk factors.

\begin{tabular}{|l|c|c|}
\hline & & GDM \\
\hline NO RISK & 714 & 20 \\
\hline Both parents DM & 69 & 4 \\
\hline$>35$ yrs & 7 & 4 \\
\hline Father DM & 78 & 2 \\
\hline Mother DM & 72 & 15 \\
\hline Prev Preg GDM & 32 & 15 \\
\hline Others Total & 30 & 5 \\
\hline \multicolumn{2}{|c|}{} & 65 \\
\hline $\begin{array}{c}\text { RISK FACTOR STRATIFICATION IN THE } \\
\text { TOTAL POPULATION STUDIED(1002 Patients) }\end{array}$
\end{tabular}

The main reason for development of GDM as per my study was:

1. History of Diabetes mellitus in mother.

2. History of GDM in previous pregnancy, similar findings were observed in studies done by Torloni Et al, 2009; Proceedings of the $4^{\text {th }}$ international workshop conference on GDM Chicago, 1998.

- Advanced maternal age and increased BMI was the main reason for development of GDM

- PCOS was the main reason for development of GDM according to Toulis Et al, 20094

- Essential Hypertension was the main reason for development of GDM

- Monozygotic twins 70\% and Dizygotic twins in 20\%-30\% were the reasons for development of GDM

- $\quad$ NO Risk factors in $50 \%$

$\checkmark$ Percentage of GDM IS $6.48 \%$ (65 patients) according to the study done in SRMC,

$\checkmark$ The percentage of GDM differs based on the population studied.

\section{6\% (Assuit university)}

- Abnormal URIC ACID and GDM in 41 patients (16.205\%)

$\mathrm{P}=0.001$ (therefore SIGNIFICANT)

AJOG, vol 201, issue 4, oct 2009 - showed 46.6\% co-relation between abnormal uric acid concentration andGDM ${ }^{2}$ Assuit university showed $12.6 \%$ co-relation $^{7}$ 
CONCLUSION: My study co - relates in assessing $1^{\text {st }}$ trimester uric acid concentration in pregnant women to predict the development of GDM.

\section{REFERENCES:}

1. WHO, Definition and diagnosis of Diabetes Mellitus and intermediate hyperglycemia, 2011, $20^{\text {thFeb. }}$.

2. Elevated first trimester uric acid level and gestational diabetes mellitus, AJOG, 2009, vol201, issue4, pg 402-403

3. White Pregnancy complicating diabetes, American Journal of medicine, 1949, vol7, pg609

4. Toulis KA, Venetis LA, risk of gestational diabetes mellitus in women with polycystic ovarian syndrome, fertility and sterility 2008 , Issue $10,16^{\text {th }}$ Oct, 1871-1873.

5. HAPO study co-op research group. Hyperglycemia and adverse pregnancy outcome. $\mathrm{N}$ engl J Med, 2008, Issue 19, 1991-2002, 463-475.

6. Torloni et al, Proceedings of the $4^{\text {th }}$ international workshop on Gestational Diabetes mellitus Chicago, 2009, 1260-1270.

7. Assuit et al, glucose tolerance and risk of Gestational Diabetes mellitus in nulliparous women. J epidemiology 2004; vol 160, Issue 12, 1205-1213.

\section{AUTHORS:}

1. Shery Angel Rajakumar

2. Thirumal $\mathrm{R}$

3. Usha V

4. Rontgen $\mathrm{R}$

\section{PARTICULARS OF CONTRIBUTORS:}

1. Assistant Professor, Department of Obstetrics and Gynaecology, Chettinad Hospital \& Research Institute.

2. Senior Resident, Department of Orthopedics, Chettinad Hospital \& Research Institute.

3. Professor, Department of Obstetrics and Gynaecology, Sri Ramachandra Hospital and Research Institute.
4. Intern, Department of Obstetrics and Gynaecology, Sri Ramachandra Hospital and Research Institute.

\section{NAME ADDRESS EMAIL ID OF THE CORRESPONDING AUTHOR:}

Dr. Shery Angel Rajakumar,

Chettinad Hospital and Research Institute,

Kelambakkam, Chennai,

Tamilnadu - 603103.

Email- sheryangel@gmail.com

Date of Submission: 10/12/2013.

Date of Peer Review: 11/12/2013.

Date of Acceptance: 19/12/2013.

Date of Publishing: 08/01/2014 